\title{
鋼柱脚ベースプレートの変形 (続報)
}

\section{1. 序}

前報(1) (ベースプレート上飞柱主材のみを招き、中心 忹縮荷重を加光た場合）の方法によつて、ベースプレー ト (B. PL) と基礎との間の各部の応力（変形）の分布 状態を求めることができたので、今回はウイングプレー ト (W．PL)，サイドアングル（S．L) 等をつけ加えた 鋼柱脚をリベット構造执よび溶接構造によつて製作し、 中心圧縮荷重並び種々の偏心荷重を加える各場合につ いて、応力分布状態を求めたものを報告する。

\section{2. 実験方法}

i) 測定般

前報のよう亿底盤 $270 \mathrm{~mm} \times 269 \mathrm{~mm} \times 8 \mathrm{~mm}$ （厚）の 㾏ぼ正方形の平滑な鋼板飞、測定脚 $(10 \mathrm{~mm} \times 10 \mathrm{~mm} \times 18$ $\mathrm{mm})$ を $9 \times 8$ 列合計 78 個植えつけ、これ机ワイヤース トレーンゲージ（W.S.G）をはりつけたものを用いた。

ii) 試験体

第1図（a）のように I 形柱主材を W. PL 抽よび S.L 等によつて、B. PL 飞取付けたリベッ卜構造の場合 (リ ベット径 $10 \mathrm{~mm} \phi$ ) と、同図 (b) の上う飞同形の主材を W,PL、リブ等によつて、B. PL 取付けた溶接構造（主 として全周隅肉溶接）の場合とであつて、これらを 4 本 又は 6 本の $13 \mathrm{~mm} \phi$ アンカーボルト (A. Bt) 飞よつて

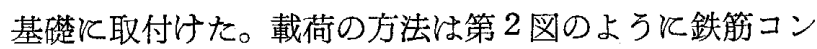
クリート造のはりをるつ基礎上飞柱を立て、これそアー ムを取付けて全体を［型と組立てて載荷した。各試験体 共中心圧縮荷重の場合並び作心を $100 \mathrm{~mm}, 200 \mathrm{~mm}$, $400 \mathrm{~mm}$ ，特よび $600 \mathrm{~mm}$ とした各場合について行つた。

$\begin{array}{ccccc}\text { 正会員 } & \text { ○田 } & \text { 口 } & \text { 武 } & \text { 一* } \\ \text { 準会員 } & \text { 西 } & \text { 島 } & & \text { 瑛** } \\ \text { 同 } & \text { 山 } & \text { 名 } & \text { 幸 } & \text { 子*** }\end{array}$

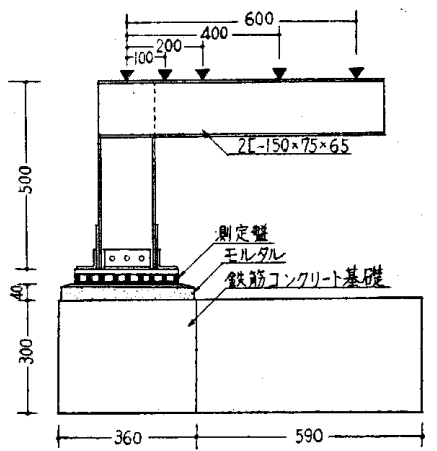

第 2 図

iii）応力の測定方法

中心圧縮荷重の作用する場合呿よび A. Bt の締付力 による応力分布の測定の場合には、前報の方法のように 第 3 図の中央部分を除く 4 区域の測定脚の W.S.G を連 結し、B.PL の約 $1 / 4$ 部分を測定すること飞よつて全 体の電気的平均值を求妨方法を用い、中央部分は同図 の上下の相対するものを連結して測定したが、偏心荷重 の作用する場合（同図上下方向の偏心）飞注同図の A,D 特よび B，C の区域の測定脚の W.S.G を連結し、中央 部分と B. PL の約 $1 / 2$ の部分（左右）の測定值（電気 的平均) から B.PL 全体の応力を求めた。

3. 材 料

i）測定盤

前報飞詳細な報告があるから省略する。

ii) 鋼 材

リベット構造怙よび溶接構造の各場合共飞、B. PLの 仕上の厚さは $16 \mathrm{~mm}$ であるが、その組立てに先立ち厚さ

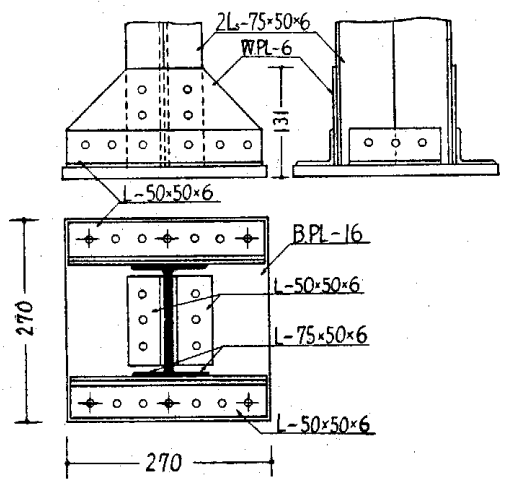

第1図（a）リベット構造

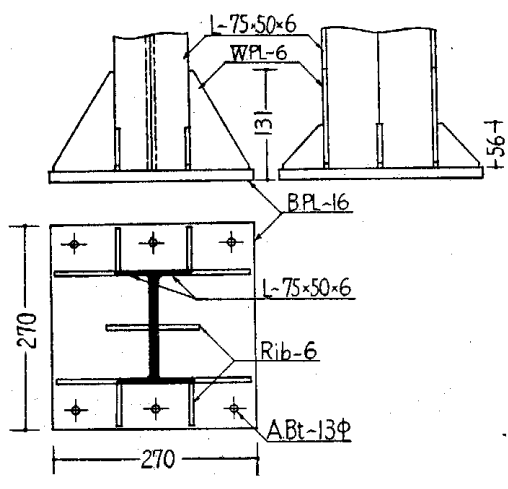

第 1 図 (b) 溶接構造
A

回 回回回; 回回回 回

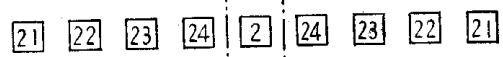

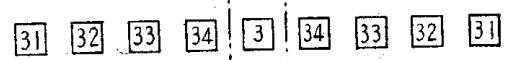

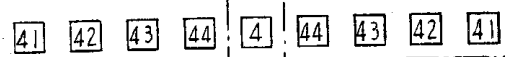

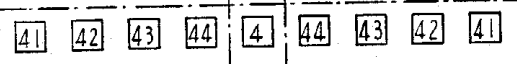
(31) 32 33 34; 3 ; 34 33 32 31

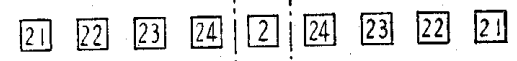
B 回回回回回!回回回回

第3 図 測定脚の区域々記号
* 横浜国立大学教授 工博 工学部建築学教室

** 吉崎建設 $\mathrm{K} \mathrm{K}$

***国宝姫路城修復工事事務所
$19 \mathrm{~mm}$ の鋼板の底面を一応平滑に仕上げ、組立完了後に、 サラリベット頭による不陸、括よび溶接による若干のひ ずみをプレーナーによつて完全に取除き平滑に仕上げた。 
柱主材は $4 \mathrm{~L}_{\mathrm{s}} \sim 75 \times 75 \times 6$ のものから $4 \mathrm{~L}_{\mathrm{s}} \sim 75 \times 50$ $\times 6$ 亿仕上げて I 型飞溶接して組立てたものである。

iii）基礎和よびっなぎぼり

コンクリートは調合 $1: 2: 3.14$ (重量比), w/c $60 \%$, ス ランプ $19 \mathrm{~cm}$, コンクリート標準試験による $4 \mathrm{~W}$ 圧縮 強度 $256 \mathrm{~kg} / \mathrm{cm}^{2}$, 基礎上面仕上モルタル（厚 $40 \mathrm{~mm}$ ) は 調合 $1: 2, w / c 60 \%$, 砂 $0.6 \mathrm{~mm}$ 以下、セメント標準試 験方法に準ずる $4 W$ 圧縮強度 $317 \mathrm{~kg} / \mathrm{cm}^{3}$ のものを用
いた。メモルタルの上面を特に平滑に仕上げるために、 モルタル打設直後に B. PL K相当する平滑な鋼板をこ の上飞招き、A. Bt 飞よつて鋼板下面を水平飞保ちなが らこれを軽く締めつけ、モルタルの硬化直後にこれを取 除いて、この表面の完全な水平面を作つた。

\section{4. 実験結果の考察}

ここには数多くの実験の中から代表的なるののみを選 んで次表のように列挙する。

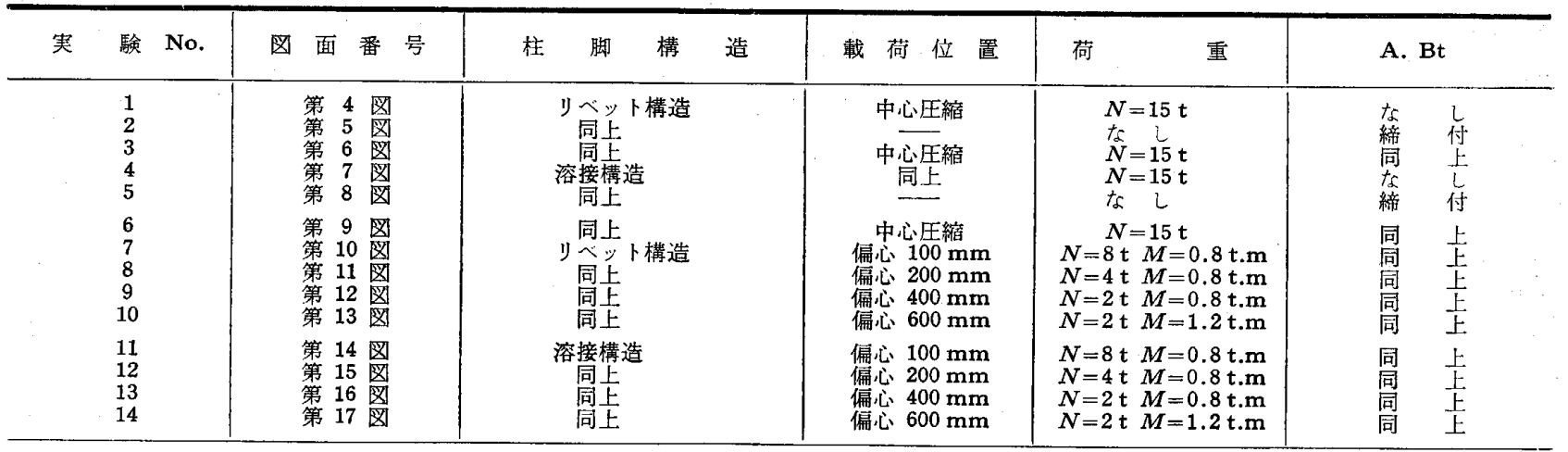

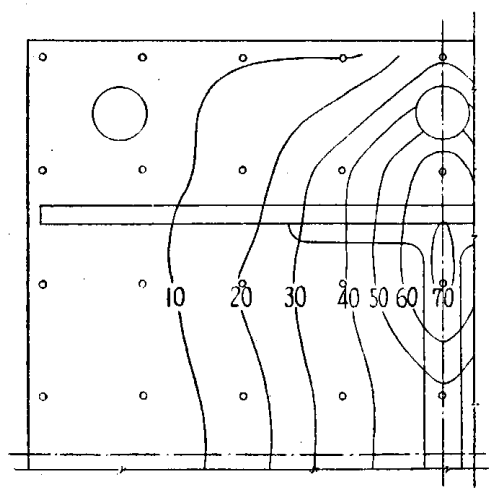

第 4 図

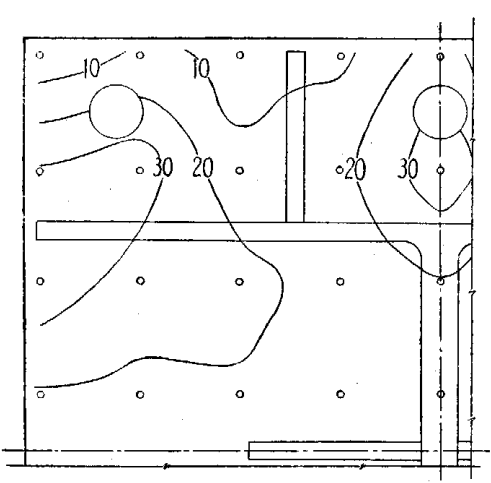

第 7 図

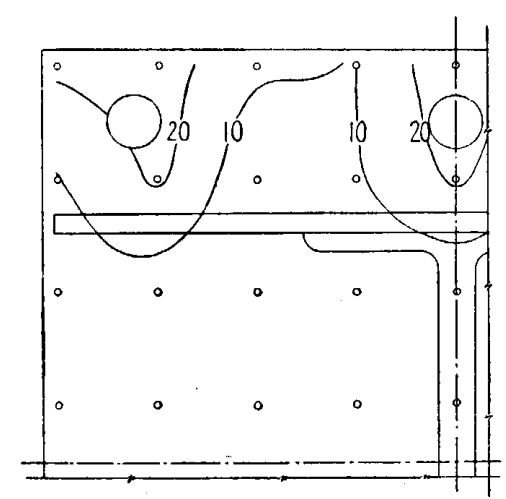

第 5 図

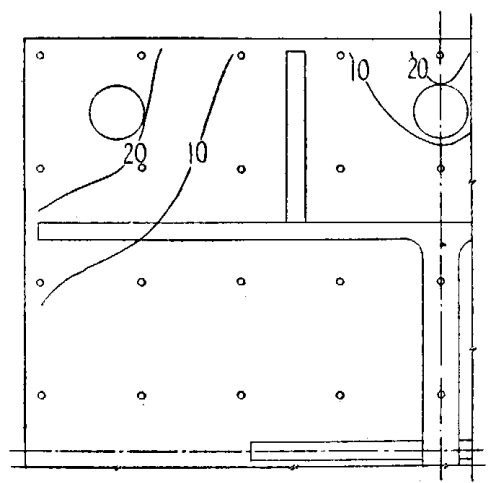

第 8 図

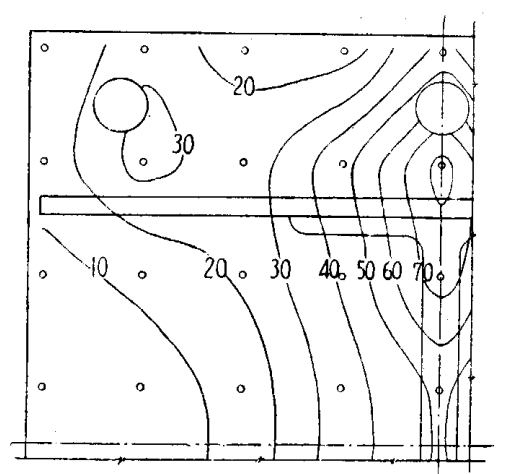

第 6 図

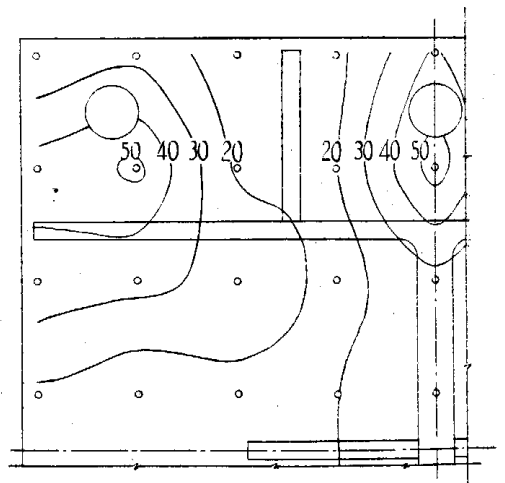

第 9 図
第 4 図〜第 17 図に示した応力の分布は各測定脚のひ ずみからとの分担面積の割合に応じて応力度 $\left(\mathrm{kg} / \mathrm{cm}^{2}\right)$ 飞換算し、等応力度部分を連絡したコンターライン (C.L) によつて示したものである。A. Bt の締めつけ力はすべ て1本についてトルク $300 \mathrm{~kg} . \mathrm{cm}$ とした。

中心压縮荷重の作用する場合、リベット構造（第 4 図 ～第 6 図）と溶接構造（第 7 図～第 9 図）の C.L を比 較すれば、A．Bt．締付力の分布には大差がないが、軸 方向力による応力分布は, 明か飞前者の場合に忹との集
中度が著しく、後者の場合には B. PL 全体に広く分布 していることがわかる。これは溶接構造の柱の軸方向力 は W. PL によく伝わつていることを示している。然し ながら溶接構造のリブに柱，住とえど力が伝わつていな いように見られることは意外なことである。

偏心荷重の作用する場合飞も第 10〜13 図*と第 14〜 17 図*を比較することによつて、中心圧縮荷重の作用す * 図中 C.L.(破線) が0のすのは塞験によつて求まつた 中立軸、理 (破線) とあるのは鋼構造計算規準の方法 によつて求めた中立軸である。 


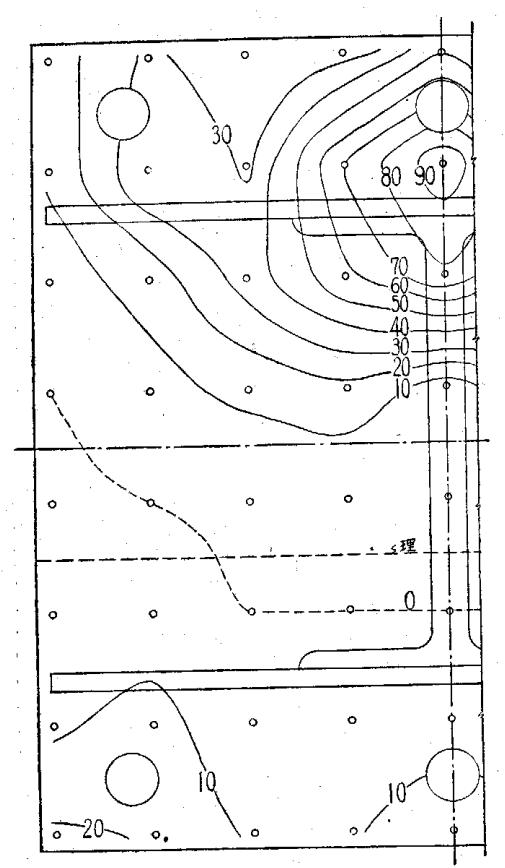

第 10 図

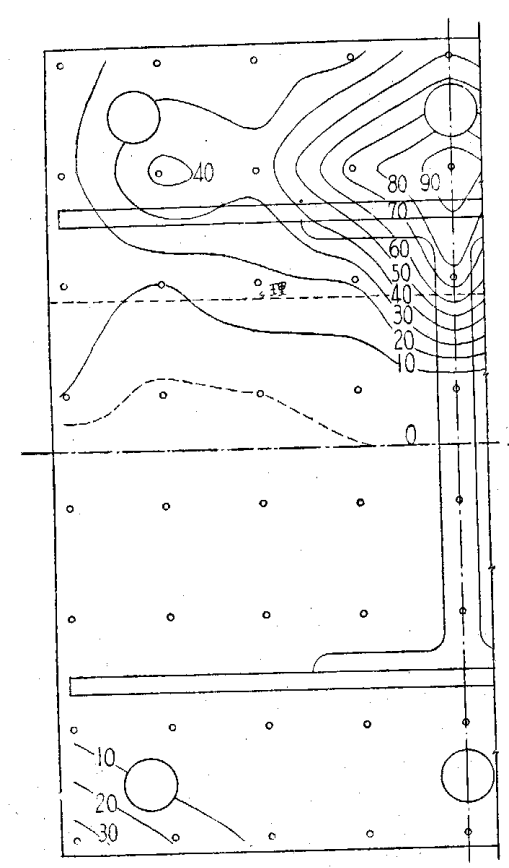

第 13 図

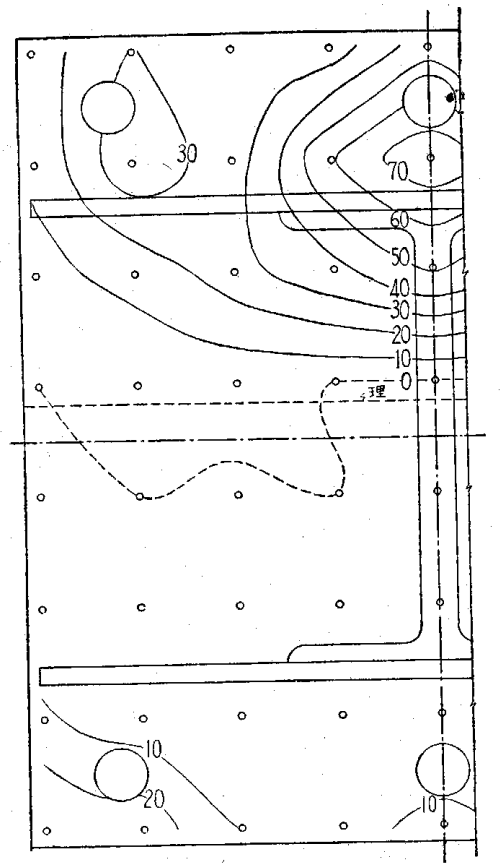

第 11 図

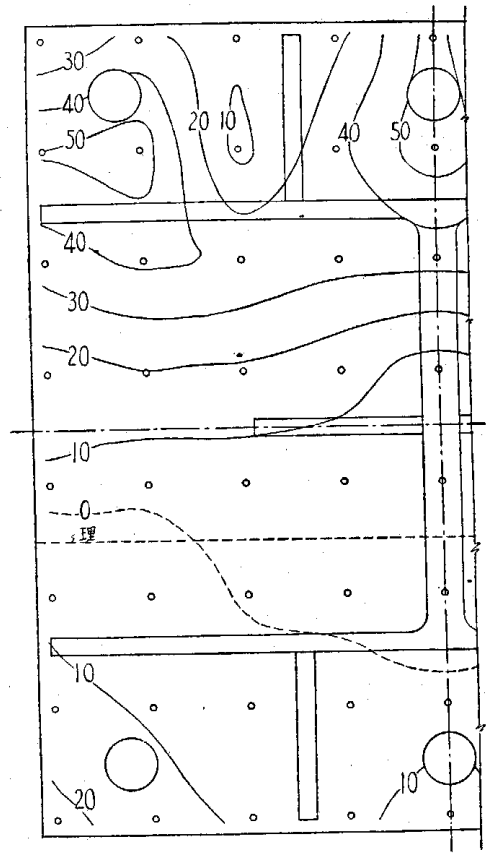

第 14 図

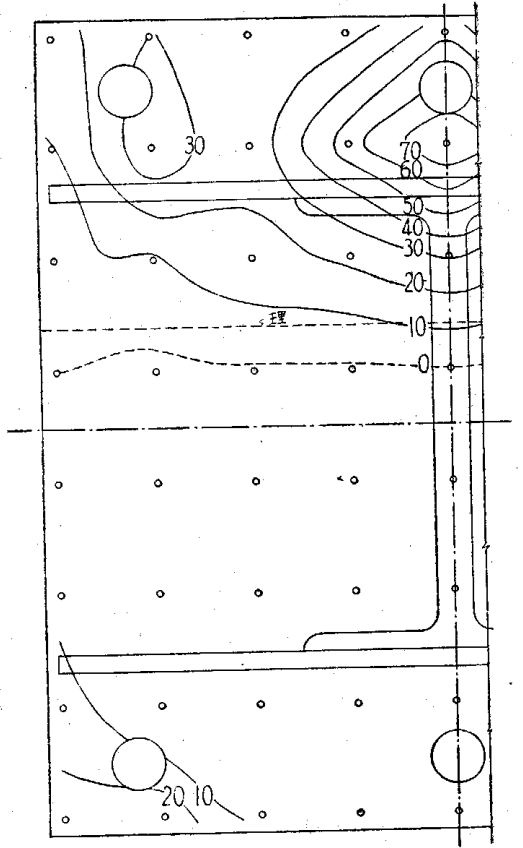

第 12 図

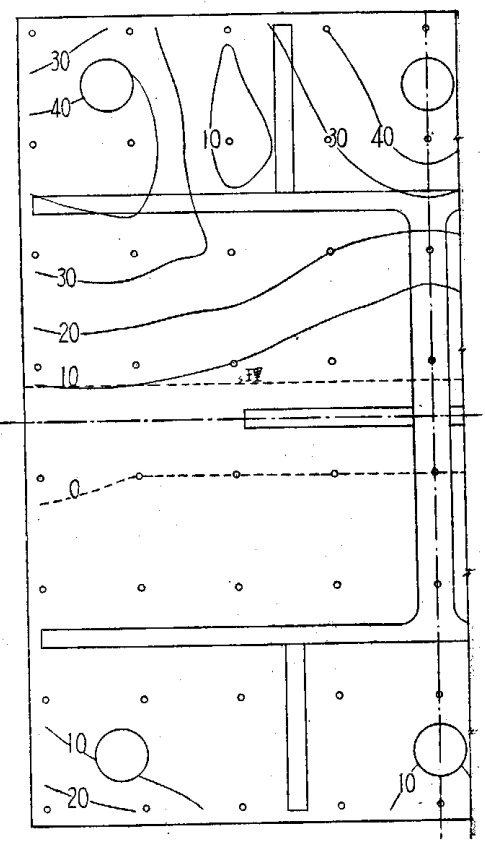

第 15 図
る場合と同じような傾向が見られる。

引張側の A. Bt ほ雨構造の場合共に偏心が増大する に徉つて次第に引張力が増大し、A. Bt の締付力による 元応力の C.L が消えて行く傾向が見られるの当然の ことであるが、3本の A. Bt のうち中央の A. Bt には 両側の 2 本の\&のに比較して著しく大なる引張力が作用 していることがわかる。

次に第 10１7 図の中から偏心荷重の作用する方向の

B. PL 中央部（柱材のウエッブの位置）に和ける応力 の分布状態を各偏心について比較すれば第 18 図(リベ ッ卜構造）秥よび第 19 図（溶接構造）が得られる。こ
の中リベット構造の場合には B.PL の中央の部分（第 3 図測定脚の上下の $|\overline{14}|$ で囲まれる部分）の忘力と両側の

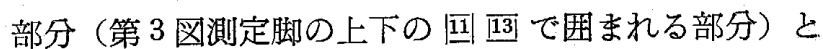
では著しい差があるので、それぞれの部分の平均值によ つて二つに分けたが、溶接構造の場合には W. PL 方向 の応力にリベット構造の場合程著しい差がないので、そ の方向の平均值で表わしてある。これによれば応力の分 布状態は現行の鋼構造計算規準の算定法と著しい差が生 じていることがわかる。

5. 結

B. PL と基礎との間の圧縮応力を測定し、等応力度間 


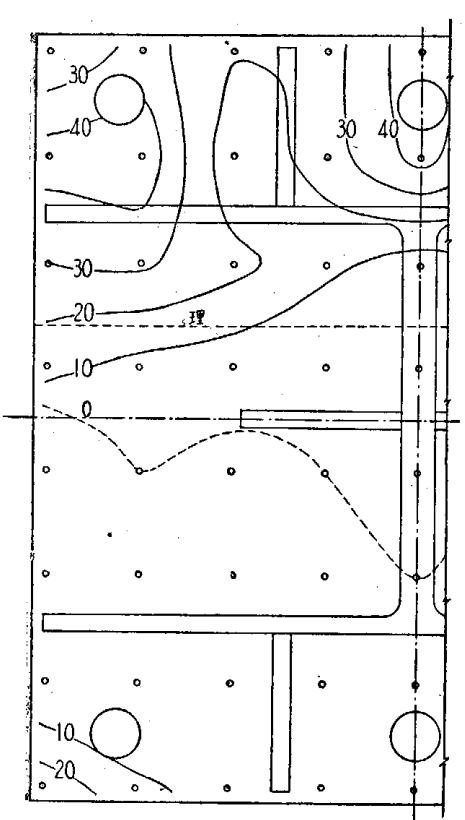

第 16 図

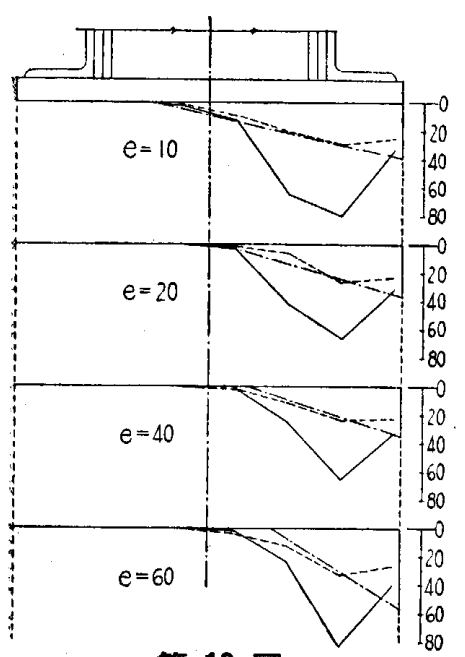

第 18 図

図中実線：理論值

破線：両側部実験值

鎖線：中央部実験值

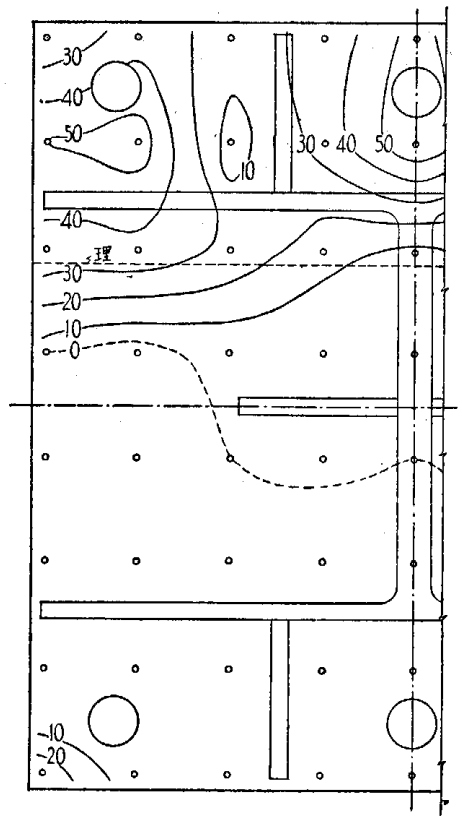

第 17 図

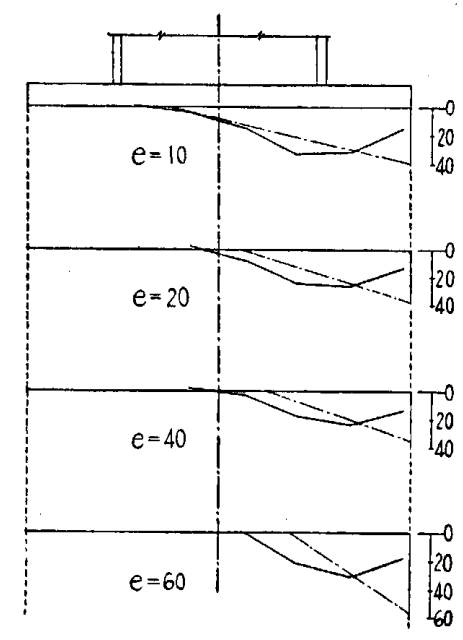

第 19 図

困中～実線：理論值

破線：実験值（平均）
を結ぶコンターラインによつて応力分布状態の 概略を知ることができた。鋼柱脚部の設計と関 する一資料としたい。

[参考文献]

（1）田口・小泉：鋼柱脚ベースプレートの 変形 論 文報告集第 60 号・昭和 33 年 10 月

（2）田口武一：鋼柱脚の固定度飞関する実 験的研究

（その 1）論文集第 51 号、昭和 30 年 9 月

（その 2） 同第 52 号、昭和 31 年 3 月

（その3） 同第 53 号、昭和 31 年 6 月

（その 4）論文報告集第 55 景、昭和 32 年 2 月

(3) George C. Priester, C.H. Sandberg: Strain Tests on Steel Plates Carry. ing $\mathrm{H}$-Section Columns

Engineering News-Record, March 19, 1931. 